Brazilian Journal of Political Economy, vol. 40, $n^{\circ}$ 4, pp. 587-603, October-December/2020

\title{
The decline of neoliberalism: a play in three acts*
}

\author{
O declinio do neoliberalismo: uma peça em três atos
}

FERNANDO RUGITSKY******

RESUMO: O objetivo deste artigo é examinar as consequências políticas e econômicas da pandemia causada pelo novo coronavírus, colocando-a no contexto de um interregno gramsciano. Primeiro, o desmonte da articulação triangular do mercado mundial que caracterizou a década anterior a 2008 é examinado. Segundo, a onda global de protestos e os deslocamentos eleitorais observados desde 2010 são interpretados como evidências de uma crise da hegemonia neoliberal. Juntas, as crises econômica e hegemônica representam o interregno. Por fim, argumenta-se que o combate à pandemia pode levar à superação do neoliberalismo.

PALAVRAS-CHAVE: Crise econômica; hegemonia neoliberal; interregno; pandemia.

ABSTRACT: This paper aims to examine the political and economic consequences of the pandemic caused by the new coronavirus, setting it in the context of a Gramscian interregnum. First, the dismantling of the triangular articulation of the world market that characterized the decade before 2008 is examined. Second, the global protest wave and the electoral shifts observed since 2010 are interpreted as evidence of a crisis of neoliberal hegemony. Together, the economic and hegemonic crises represent the interregnum. Last, it is argued that the fight against the pandemic may lead to the overcoming of neoliberalism. KEYWORDS: Economic crisis; neoliberal hegemony; interregnum; pandemic. JEL Classification: B51; E02; O57.

\footnotetext{
* A previous version of this paper was published, in Portuguese, in the 1st edition (2nd series) of Revista Rosa. ** Professor at the Economics Department of Faculdade de Economia e Administração da Universidade de São Paulo - FEA/USP, São Paulo/SP, Brasil. E-mail: rugitsky@usp.br. Orcid: https://orcid.org/00000002-4803-7270.

*** Principal Investigator of the Maria Sibylla Merian Centre Conviviality Inequality in Latin America (Mecila). I debated the ideas suggested in this paper with several people and received numerous excellent comments. Acknowledgment is due to André Singer, Carlos Henrique Árabe, Cicero Araújo, Eleutério Prado, Federico Naspleda, Felipe Amaral, Hugo Fanton, Leda Paulani, Lena Lavinas, and Thais Pavez. Bruno Höfig, Flávio Prol, José Bruno Fevereiro, Juan Grigera, Lucia Del Picchia, Luiz Carlos BresserPereira, Marcela Vieira, Pedro Loureiro, Rodrigo Toneto, and Ronaldo Herrlein Jr. generously commented a preliminary version of this article, stimulating me to improve the final presentation of the argument. Acknowledgment is also due to the Brazilian Coordination for the Improvement of Higher Education Personnel (CAPES) for the funding that made this research possible. Submitted: 29/June/2020; approved: $7 / \mathrm{July} / 2020$.
} 
Come writers and critics

Who prophesize with your pen

And keep your eyes wide

The chance won't come again

And don't speak too soon

For the wheel's still in spin

And there's no tellin' who that it's namin'

Bob Dylan, The Times They Are A-Changin’ (1963)

This article was planned before the pandemic caused by the new coronavirus. Its initial aim was to interpret the political and economic uncertainties bequeathed by the crisis that broke out in 2008. It would be, thus, one more paper that could resort to Antonio Gramsci's formulation that became a cliché in the critical debate of the last few years: "The crisis consists precisely in the fact that the old is dying and the new cannot be born; in this interregnum a great variety of morbid symptoms appear" (Gramsci, 1930-1971: 276). ${ }^{1}$

Amid the current pandemic, maybe the most sensible thing to do would be to suggest that the uncertainties are even greater. Daily life was suddenly and radically transformed and there is no reliable forecast of when the virus will be under control. However, there seem to be evidence that indicate that the current tragedy will bring the Gramscian interregnum to an end and that the new will be born from its debris. The political, economic, social, and cultural changes that may be unleashed by the fight against the pandemic are too difficult to predict and depend in part on the length of the lockdown currently in place in several places. This article does not intend to offer specific forecasts in this regard. It aims only to suggest that neoliberalism will, at last, be left behind. To do that, the results of the crisis that broke out in 2008 are examined and, in the end, an attempt to substantiate that bet is undertaken.

\section{ECONOMICS AND POLITICS SINCE 2008}

The weaknesses of the financial systems of the rich countries started to surface in 2007, with the decline of housing prices and its effects on the mortgage market. But the crisis would only erupt on Monday, September 15th, 2008, when the investment bank Lehman Brothers filed for bankruptcy in the United States. Since then,

\footnotetext{
${ }^{1}$ If I am not mistaken, the title of the 2011 Historical Materialism annual conference in New York was based on that quotation. Likely, it was not the first reference to it after 2008. Last year, Nancy Fraser (2019) and Sabrina Fernandes (2019), to mention two examples, used different parts of this formulation in the title of their books. For an examination of the pandemic that relies on the related concept of "organic crisis", see Levenson (2020).
} 
the endless chain of economic and political crises has been so overwhelming that it is hard to provide an overview. A brief chronology of the main events might help. ${ }^{2}$

The financial implosion of 2008 froze financial markets and brought the world economy to a recession in 2009 , despite the coordinated reaction of governments to attenuate its effects. In 2010 and 2011, the epicenter of the crisis crossed the North Atlantic and settled in the Eurozone. The Euro crisis was described by Adam Tooze (2018: 21) as "a massive aftershock of the earthquake in the North Atlantic financial system of 2008, working its way out with a time lag through the labyrinthine framework of the EU [European Union]". Public bonds of the countries at the periphery of the monetary union started to come under speculative attacks that made the recovery of the European economy unfeasible: Eurozone GDP fell again in 2012 and 2013 and increased slowly since then. The most affected countries in this stage were Ireland, Portugal, Spain, Italy, and Greece. Financial markets' inclination to create acronyms took an ironic turn and these countries were grouped under the rubric PIIGS, formed by its initial letters.

Continuing its course to the East, the crisis started to have a deeper effect on Asia in 2012, decelerating the Chinese economy in particular. The growth of its GDP fell below $8 \%$ (something that happened only twice since 1991) and, since then, it went on decelerating gradually, year after year. ${ }^{3}$ Completing its course around the globe, the economic effects of the crisis, through the deceleration of the Chinese economy, brought the commodities boom to an end, in the second semester of 2011, affecting the economies that export primary goods, including Brazil and its South American neighbors.

Between the end of 2010 and 2013, the political effects of the global crisis started to manifest themselves more clearly with the occurrence of a global protest wave. According to Paolo Gerbaudo's (2017: especially p. 33, Figure 1.1) account, between December 2010 and March 2011, the Arab Spring broke out in Tunisia, Egypt, Bahrain, Libya, and Syria. In May 2011, the rebellious wave crossed the Mediterranean and settled in the squares of Spain (the Indignados) and Greece. In September of that same year, it reached the United States, with Occupy Wall Street, which initially erupted in New York but soon spread across the country. Before the end of 2011, a similar occupation took place in London, at the entrance of St. Paul's Cathedral. In 2013, the rebellion went on, with occupations in Istanbul, starting in May, and the protests that brought Brazil to a halt, in June. Later, similar protests would take place also in Hong Kong and France (from the Nuit Debout to the Gilet Jaunes). Referring specifically to the Spanish and Greek cases, Tooze (2018: 314) said: "[t]he crisis had leaped from the financial to the political sphere."

Starting in 2014, the repercussion of this global protest wave in the institu-

\footnotetext{
${ }^{2}$ The most complete and interesting narrative of this period may be the one offered by Adam Tooze (2018).

${ }^{3}$ Data mentioned in this article is from the World Bank, except when otherwise indicated, and can be accessed in data.worldbank.org.
} 
tional sphere became clearer, bringing about a widespread electoral decline of the centrist parties, challenged by alternatives to the left and the far-right. Among the left, it is worth mentioning Podemos, founded in 2014, which already by 2015 had conquered more than $20 \%$ of the vote in a general election (becoming Spain's thirdlargest party). Also in 2015, Jeremy Corbyn won the leadership election for the United Kingdom's Labour Party, unleashing a major shift in the party's political stance, and Syriza, a Greek party, rose to power. In 2016, it was the United States' Democratic Party's turn to be shaken by a grassroots movement that pushed it towards the left, in the context of the candidacy in the primaries of an independent senator, Bernie Sander, who claims to himself the label of a democratic socialist. ${ }^{4}$

On the side of the far-right, the electoral ascendancy was more successful. From 2016 onwards, politicians with similar discourses, which were previously marginalized in the public debate, increased their influence and rose to power in several countries. Duterte became Philippines' president in 2016 and Trump of the United States in 2017. Salvini rose to the position of vice-prime-minister in Italy in 2018 and Bolsonaro was inaugurated as Brazil's president in 2019. The four of them walked on the trail opened by other right-wing leaders that had risen to power before, like Erdogan (prime-minister of Turkey between 2003 and 2014 and president since then) and Orbán (prime-minister of Hungary since 2010). These electoral victories were part of a broader trend. As Brank Milanovic (2016: 209) has shown, the percentage of votes won by far-right parties increased substantially since 2012 in several European countries, including Austria, Denmark, Finland, France, Germany, Greece, Sweden, and the United Kingdom. A last noteworthy electoral upset was the result of the referendum on Brexit. Challenging the preference of most leaders of the two main British parties (the Conservative and the Labour), a majority of voters decided to leave the European Union. The main discourse that mobilized them had something in common with the platform of some of the far-right leaders: xenophobia.

\section{FIRST (ECONOMIC) ACT: TRIANGULAR ARTICULATION AND THE DOMINO EFFECT}

A possible starting point to understand this chain of economic and political convulsions is examining how capital accumulation was geographically articulated before 2008. In other words, examining the workings of the world market in the run-up to the crisis. Robert Blecker (2016: 211) argued that, until 2008, "global growth was sustained by a triangular pattern of trade imbalances, financial flows and demand transmission among three groups of countries: the deficit countries or net demand generators (for example, US, UK), the manufacturing exporters (for example, China, Germany) and the primary commodity exporters (for example, Russia, Brazil)."

\footnotetext{
${ }^{4} \mathrm{~A}$ joint assessment of these alternatives on the left was written by Susan Watkins (2016).
} 
This pattern represents the world market articulation in the decade that preceded the crisis with precision. Between 2001 and 2006, the United States' current account deficit more than doubled, increasing from around 389 billion dollars to more than 805 billion. $^{5}$ This steep rise meant an enormous increase in demand, channeled especially to the countries that were consolidating themselves as the new "workshops of the world": China, Germany, and Japan. Between 2001 and 2008, China's current account surplus rose from around 17 to more than 420 billion dollars. ${ }^{6}$ Germany, in its turn, also stimulated by the exchange rate devaluation resulting from the adoption of the Euro, transformed the current account deficit that the economy exhibited in every year between 1991 and 2001 into a surplus, which, in 2007, reached 235 billion dollars. Last, Japan, which already showed notable surpluses since the 1990s, reached the pre-crisis peak also in 2007, with a surplus larger than 211 billion dollars.

These current account data suggest the nexus between the demand generating countries and the new workshops of the world but do not indicate clearly the magnitude of the rise of the countries included in this second group. In 2000, while the United States was responsible for more than $15 \%$ of world exports, China, Germany, and Japan together accounted for just above 16\%. In 2015, the exports from the new workshops of the world represented $22.5 \%$ of world exports and the United States' exports had been reduced to $12.2 \%$. The growth of the share of the former group was due basically to China's, which saw its share rise from $2 \%$ to $10 \%$ of world exports between 2000 and 2015. China's GDP, which was about a third of the United States' in the late 1990s (calculated in purchasing power parity terms), became the world's largest in $2014 .^{7}$

The abundant demand for goods and services by the people from the demand generating countries (United States, United Kingdom, and the European periphery, roughly speaking) was not sustained by substantial increases in their incomes, as could have been expected. Most of the population from these countries faced decades of stagnant wages, as a consequence both of the weakening of trade unions, attacked by neoliberal governments, and the transfer of a significant share of jobs with relatively higher wages to the new workshops of the world - leaving behind numerous rustbelts. ${ }^{8}$ The continuous improvement of their consumption patterns, despite stagnant wages, was allowed for by rising indebtedness, partly stimulated

\footnotetext{
${ }^{5}$ Data in this paragraph are always in current values.

${ }^{6}$ That does not mean that Chinese growth was entirely determined by foreign demand, rather that this demand contributed to it. There is a controversy in the literature about the Chinese growth strategy, with arguments for and against its characterization as an export-led strategy. See Medeiros (2010) and Tooze (2018: 246-7).

${ }^{7}$ See, on this issue, Milanovic (2019: 9-10). In current dollars, the United States' GDP is still larger than China's.

${ }^{8}$ According to estimates by Emmanuel Saez (2013: 125), between 1993 and 2012 the income of the top $1 \%$ in the United States grew in real terms $86.1 \%$, while the income of the remaining $99 \%$ rose only $6.6 \%$. The antagonism between the $1 \%$ and the remaining $99 \%$, which came to the fore with Occupy Wall Street, has a clear material basis.
} 
by asset bubbles (housing bubbles, mainly). As Aldo Barba and Massimo Pivetti (2009) argued, debt was a substitute for wages. ${ }^{9}$

The United States' case is well known, maybe because it was the initial epicenter of the financial crisis. There seems to be no need to go back to examining the housing bubble that took place in the years before the crisis and its relation with the fragile financial pyramid, teeming with subprime loans (see, for instance, Duménil and Lévy, 2011). But it should not be overlooked that similar processes took place in the United Kingdom and the European periphery. The increases in housing prices observed between 2001 and 2006 in the United Kingdom, in Greece, in Spain, and in Ireland were larger than the one registered in the United States. In the case of the European periphery, the adoption of the Euro created a sudden abundance of cheap credit that unleashed a cumulative process: rising asset prices (including housing) increased the borrowing capacity of households and such borrowing, in its turn, fuelled rising demand and further increases in asset prices (López and Rodríguez, 2011; Tooze, 2018: chap. 4).

The provision of an unprecedented amount of credit to the households guaranteed, simultaneously, demand for a significant part of global output and some political stability, attenuating (though very modestly) the effect of income inequality on the inequality of consumption patterns. It was a provisory solution to the problems of realization and legitimation, which had as a side effect an aggravation of working-class subordination (there is a vast literature suggesting that debt has a disciplinary role; see the works mentioned in Kim, Lima, and Setterfield, 2019). Such a solution was doomed to be temporary, however, given that it created the immense financial vulnerability that surfaced in 2008 .

The 2008 crisis interrupted this order of things, increasing economic uncertainty and knocking down the world economy in 2009. Immediately, monetary authorities acted to save financial institutions and restore, as if nothing had happened, the previous status quo. However, such restoration proved to be unviable. The sudden reduction of income and wealth of the working classes by, respectively, unemployment and the fall of the housing prices imposed a long process of deleveraging, blocking the resumption of borrowing. Even though central banks reduced interest rates to zero and injected immense quantities of money in the credit markets (the so-called quantitative easing), the vast majority did not recover its capacity to borrow for consumption.

In light of the workings of the world market in the period, the dismantling of the cumulative process that sustained consumption in the demand generating countries represented the fall of the first domino that would impact, with a lag, the workshops of the world and, then, the primary commodities exporters. The gradual dislocation of the crisis to the East was the result of the triangular articulation of the world economy. The commodities boom was the expression of the impulse

\footnotetext{
${ }^{9}$ According to Wolfgang Streeck (2014), household indebtedness represented one of the temporary solutions to the tensions of democratic capitalism.
} 
produced by China in the third vertex of the triangle, which includes some countries form South America and Africa, in addition to Russia. In a detailed empirical assessment of the primary commodities prices since the 19th century, Bilge Erten and José Antonio Ocampo (2012: 14) maintained that "[t]he remarkable strength and length of this [recent] upswing in commodity prices reflect the extraordinary resilience of growth performance of major developing country demanders of commodities, particularly China.” Kevin Gallagher (2016: 7) exposes this nexus more concretely:

As China has risen, it has been guzzling oil from Venezuela, Ecuador, and Mexico to fuel its expanding fleet of cars, trucks, and container ships. China has wired more than half the world's consumer electronics products with copper from Chile and Peru. Much of the steel in China's new cities is made with iron ore from Brazil at their core. As standards of living have risen, the Chinese eat more beef from cattle that are fed soya beans from Argentina and Brazil.

With the decline of the demand generating countries, the workshops of the world had to slow down the pace of their accumulation and shift increasing shares of its output towards their domestic markets. Primary commodities exporters, on their turn, faced falling prices in the international markets and pressure on their current accounts. With the end of the commodities boom, the impulse that had given them dynamism in the decade before the crisis was inverted, pulling these economies down. The successful countercyclical policies adopted by the Brazilian government in 2008 and 2009 contributed to attenuate the short-term shock, reducing it to a marolinha (a small wave, the expression used dismissively by president Lula in the occasion). ${ }^{10}$ But the structural shock would come in a few years, through China, with the dismantling of the triangular articulation that underpinned the commodities boom. This shock was one of the determinants of the huge economic, political, and social crisis that broke out in Brazil in 2014.

\section{SECOND (POLITICAL) ACT: GLOBAL CRISIS, LOCAL SPECIFICITIES}

Examined, however briefly, the economic aspects of the crisis, its political dimension remains to be tackled. The global wave of protests that began in 2011 and that, a few years later, decimated several centrist parties suggests that the economic crisis became a legitimation crisis. In this sense, Nancy Fraser argues that it is necessary to distinguish between neoliberal policies and neoliberal hegemony. While the former are still being implemented (or were, until the pandemic), the

\footnotetext{
${ }^{10}$ The recovery of the commodities prices, between 2009 and 2010, also played a role. The end of the boom took place only in 2011 and the prices of these commodities fell substantially only from 2014 onwards.
} 
hegemony has come to an end: "as a hegemonic project, neoliberalism is finished; it may retain its capacity to dominate, but it has lost its ability to persuade" (Fraser and Jaeggi, 2018: 298).

Although this hegemonic crisis has global dimensions, it seems reasonable to examine the specificities presented by the three knots of the triangular articulation. The epicenter of the political crisis is in the demand generating countries, that is, the United States and Western Europe. In these countries, the weakening of the centrist parties reflects a polarization in their class structures that is ongoing for some decades. The rise of neoliberalism allowed for the appropriation by the top $1 \%$ of growing shares of income at the same time as the transfer of production to the new workshops of the world eliminated jobs with intermediary wages, concentrating the working classes in more precarious industries, with reduced wages and higher economic insecurity. ${ }^{11}$ According to Gérard Duménil and Dominique Lévy (2004: 105), neoliberalism "has enhanced the legibility of capitalist social relationships".

In the United States, the concentration of economic power by the top was accompanied by a concentration of political power, with the weakening of democratic rules by the fall of the restrictions to corporate contributions to electoral campaigns (following the Supreme Court decision in the case Citizens United v. Federal Election Commission) and by the diffusion of strategies to suppress voting rights. ${ }^{12}$ The tendency, according to Milanovic (2016: 199-204), is the development of a plutocracy. ${ }^{13}$ In the Eurozone, the dominant strategy to contain the dissatisfaction of the great majority was not reducing their influence on government but reducing the national government's influence over policy, binding them to neoliberal policies decided for the monetary union as a whole (and never effectively endorsed by citizens)..$^{14}$ Additionally, there was always the possibility of replacing governments by technocrats aligned with the establishment, what was done in Italy and in Greece, between 2011 and 2013 (Streeck, 2016: 20, fn. 27). Such hollowing out of democratic institutions in both sides of the North Atlantic did not happen without resistance, however, and the multiplication of institutional alternatives from the left and the right blocked any stabilization, bringing the hegemonic crisis to the fore.

Among the primary commodities exporters, it is noteworthy the particularities

11 The literature on the subject is vast. Regarding the United States' case, where this process is more advanced, see among others Storm (2017), Temin (2017), and Taylor and Ömer (2020). For analyses of the impact of the decline of manufacturing employment on the election of Trump, in the United States, and on the Brexit referendum, in the United Kingdom, see respectively Davis (2017) and Hazeldine (2017).

${ }^{12}$ Such strategies are varied, including the withdrawal of voting rights of the huge number of people in prison and arbitrary documentation requirements that aim to reduce the electoral participation of the poorest groups. Maybe the most pernicious strategy, which indirectly restricts electoral participation, is the redefinition of districts, referred to as gerrymandering. See Milanovic (2016: 200-1).

${ }^{13}$ For evidence in that direction, see Winter and Page (2009), Hacker and Pierson (2010), and Gilens and Page (2014). I thank Pedro Loureiro for bringing this literature to my attention.

${ }^{14}$ See Streeck (2016: esp. chap. 5) and Tooze (2018: 330). 
of the process that resulted in political crises in the South American countries that were part of the so-called "Pink Tide". The election of left of center governments (chronologically, in Venezuela, Brazil, Argentina, Uruguay, Bolivia, and Ecuador) during the decade that preceded the 2008 crisis was already a result of an earlier weakening of neoliberal hegemony in the region. Although few of these governments abandoned neoliberal policies completely, their focus on redistributive policies, together with the transformation of their productive structures connected with the effects on the region of the rise of the Chinese economy, affected their class structures differently. Even though some reduction of relatively well-paid manufacturing jobs was observed, the predominant phenomenon in these cases is not the rustbelt. The most important transformation was the transition of a large share of the working classes from a more precarious situation to one with more economic security, something that can be understood as the absorption by the proletariat of a part of the "underproletariat" ${ }^{15}$, although the demarcation between both groups is becoming increasingly undefined by the precarization of formal labor relationships. ${ }^{16}$

In the Brazilian case, the rise of the income of the poorest groups - a result, initially, of a policy of increasing the minimum wage implemented by the Workers' Party governments and of the Bolsa Família, a conditional cash transfer program - allowed for the diversification of consumption patterns, which was met by imported production (especially Chinese) and by the domestic expansion of basic services. Such expansion affected the labor market, changing the sectoral composition of employment in a way that reduced wage inequality. In this way, a cumulative process was observed (the economic antimiracle) in which reductions of wage inequality and changes in the sectoral composition of employment were mutually reinforcing (Rugitsky, 2019).

Concretely, construction, popular commerce, and some other basic service sectors absorbed both the new entrants in the labor force as well as people previously underemployed in rural and urban areas. Estimates about the Brazilian class structure suggest that, for the first time, the proletariat has surpassed the underproletariat as a share of the labor force, as a result of this cumulative process: at the beginning of the 2010s, the former represented more than $40 \%$ of the labor force, while the latter responded for little more than $32 \%$. In 2002, the shares of the proletariat and the underproletariat were, respectively, about $35 \%$ and $39 \%$ (Rugitsky, 2020). ${ }^{17}$

\footnotetext{
${ }^{15}$ Paul Singer (1981: 22, my translation) has defined the underproletariat as the group of people that "actually or potentially supply their labor power in the market but do not find someone willing to buy it for a price that guarantees its reproduction in normal conditions", suggesting that it consisted in part of the industrial reserve army, as defined by Marx.

16 The celebratory narrative about the rise of the "middle classes" in the region, which allegedly happened during the commodities boom, did not resist scrutiny of the transformation of class structures, with more precise definitions of the different positions in the social structure. On the debate on the Brazilian case, see Singer (2012: 129-143). For the debate on Latin America as a whole, see the references mentioned in Pérez-Ahumada (2018: 156).
}

${ }^{17}$ Recent analyses of the Brazilian class structure can be found in Figueiredo Santos (2015) and Loureiro 
Perhaps the Brazilian case is not representative of the South American region as a whole, but there is evidence that similar processes characterized, at least, the productive and class structures of Argentina and, maybe to a lesser degree, of Chile. ${ }^{18}$ The legacy of the triangular articulation, in these countries, was not the social downgrading of the vast majority, but an improvement (however modest) of its situation. Consequently, the observed turn to the right is less a rebellion against the establishment, as in the rich countries, and rather an attempt by the ruling classes to resist pressures to share economic and political power. Maybe this explains why the region's right, led by Macri and Bolsonaro, pledge allegiance to neoliberalism, whereas Trump, Farage, and Le Pen reject it (although the distinction between neoliberal policies and neoliberal hegemony is crucial in the case of the Trump government; or at least it was until the pandemic). ${ }^{19}$

Bolsonaro's example reveals the necessity of considering together the local and global aspects of the crisis. The local class dynamics contributes to explain his option for neoliberalism and the fact that his electoral support has always been greater among the rich than among the poor. However, the global hegemonic crisis also had its implication in Brazil and the return to neoliberalism tout court supported by the ruling classes did not take place with the election of the traditional center-right parties that represented, in the last decades, its interests (mainly the, inappropriately named, Partido da Social Democracia Brasileira, PSDB). Such return was made viable by an, until then, marginal political character, who combined neoliberal rhetoric with a repertoire shared with the rising global far-right. His electoral success depended not only on the support of the ruling classes but also on substantial support among the popular classes, a product in part of his capacity to mobilize social suffering which resisted the limited redistribution that occurred in the previous period and was aggravated by the economic crisis that began in 2014 - and was deepened by the turn to austerity in Dilma Rousseff's second term in the presidency (Carvalho, 2019). The paradox of his electoral success was that he was able to channel a popular dissatisfaction that was also connected to neoliberalism, attributing it to corruption and proposing to combat it with, among other things, more neoliberalism. Thus, it becomes clear that, although the epicenter of the hegemonic crisis was the rich countries, it also reached other regions of the world. The weakening of democracy engendered by neoliberalism knows no borders.

The workshops of the world remain to be examined. The main case is the Chinese one. Here the situation seems to be less clear. On the one hand, China's adoption of neoliberal policies is much more ambiguous than the adoption of those

(2018: esp. chap. 4).

${ }^{18}$ For the Argentinian case, see Loureiro (2018: chap. 6). For the Chilean, see Pérez-Ahumada (2018).

${ }^{19}$ The fact that Trump's election reflects a rebellion against the establishment does not imply that he governs against the ruling classes. 
policies in the Americas or Europe. On the other, the Chinese political system has managed to keep resistance under control (except for the recent protests in Hong Kong). In 2016, Milanovic (2016: 214) speculated that rising inequality in China "may end up undermining the Chinese political system and either transforming the rule of the Communist Party into a more nationalistic and autocratic regime or pushing it toward democracy." Will the huge economic impact of the pandemic (which led to a fall of the Chinese GDP in the first quarter of this year, something that had not happened for decades) and the way that the Chinese government faced it accelerate these transformations? Bets that the new coronavirus may represent China's "Chernobyl moment" started to circulate, but it is hard to be sure whether they are not, once more, analyses biased by the orientalism dominant on the rich countries media. The question about the political trend of China likely is the most consequential to the future of capitalism.

\section{THIRD (HEALTH) ACT: THE DEATH AND THE DEATH OF NEOLIBERALISM}

The new coronavirus started to spread, moving "through the circuits of capital and the humans that labor in them" (Moody, 2020), in a world profoundly marked by the hegemonic crisis that has been brewing since 2008. In a semester, the official count indicates more than 10 million cases and 500 thousand deaths scattered across the globe, ${ }^{20}$ but it is suspected that the real numbers are much larger. It is already evident that the immediate economic impact will be a decline in economic activity significantly larger than the one that was observed in 2008. IMF's forecast published on June 24th indicates a reduction by $4.9 \%$ of world GDP, while the one that took place in 2009 was by only $0.1 \%$ (it is forecasted also a decline of $9.1 \%$ for Brazil and $8 \%$ for the "advanced economies"). According to the expression used by an institution that usually prefers euphemisms, it will be the "worst economic downturn since the Great Depression" that began in 1929 (Gopinath, 2020).

The qualitatively distinct nature of the crisis is more important than the size of the fall. Although public spending is crucial (to sustain workers' income, increase the capacity of health systems, and finance research on vaccines and treatment), there is a limit to how far governments can sustain aggregate demand, given that fighting the pandemic entails people staying at home, prevented from consuming numerous services. The economic challenge seems to be less to compensate with public spending the fall in private spending, but rather redirecting, in a planned way, the productive apparatus to fight the pandemic, reallocating people that cannot work in their usual jobs to contribute to the necessities of the health system (including the production of medical and protective equipment) and guaranteeing

${ }^{20}$ WHS (World Health Organization) data from June 30th. 
income to those who have to stay at home. Understandably, one of the most common metaphors for the current situation has been the war economy (see, among others, Vernengo, 2020).

This analogy may be fruitful also for another reason. The 1929 crisis was a watershed because it ended the laissez-faire hegemony. Gramsci's formulation about the interregnum was written in 1930 and reflected precisely that context. The birth of the new, however, would only take place after World War II, for several reasons. One of them is that the consolidation of an alternative to laissez-faire would be helped by the experience with central planning during the war effort. The diffusion of the idea of economic planning was already happening during the 1930s and the fact that the main planned economy of the period, the Soviet Union, went through 1929 relatively unscathed increased the appeal of this alternative. But the war experience was decisive, not least because of the recruitment of a large number of economists by the governments at the time, giving them practical experience with managing the production and distribution systems (Morgan and Rutherford, 1998). Famously, Paul Samuelson argued that World War II was "an economists' war" (Fogel, 2001: 214). The new that emerged from its debris, in 1945, took on the shape of the mixed economies of the "Keynesian consensus", a kind of state-managed capitalism (Pollock, 1941). ${ }^{21}$

It is plausible that history will repeat itself in this regard. If 2008 inaugurated the interregnum, the fight against the pandemic might be responsible for the birth of the new. There is abundant evidence that this new may once more take on the form of state-managed capitalism, relegating to the past not only the neoliberal hegemony but also the neoliberal policies. That does not imply taking the neoliberal rhetoric of a minimal state at face value: it is already well established that neoliberal policies do not mean a reduction of the role of the state, but a change of its character, with the multiplication of mechanisms to channel the surplus to the top and the enlargement of the repressive and carceral apparatus, just to give some examples. The replacement of neoliberalism by new state-managed capitalism would not represent, thus, simply a return to state activism, but a new direction of this activism towards restricting the scope of market competition dynamics.

The direct state control imposed by the fight against the pandemic would be unimaginable a few months ago. The Italian government nationalized the Italian airline corporation, Alitalia; the Spanish government took control of the private health system; and Trump's government, in the United States, used legislation from the Korean War to make General Motors produce ventilators (Marx, 2020; Fernán$\mathrm{dez}, 2020)$. Even the payment of the wages of the workers who are being forced to stay at home has been overtaken by governments: in the United Kingdom, the government committed to paying $80 \%$ of the earnings of self-employed and furloughed workers to a maximum of 2.500 pound per worker per month; in Den-

\footnotetext{
${ }^{21}$ Bresser-Pereira (2017) would probably call it developmental capitalism, in contrast with the liberal one. I thank Bresser-Pereira and Ronaldo Herrlein Jr. for their suggestions on this issue.
} 
mark, the government will cover $75 \%$ (Grigera, 2020).22 These examples are, of course, merely illustrations of a larger set of policies that have been adopted throughout the world. ${ }^{23}$ Most of them, it is worth noting, is aimed at attenuating the decline in profits and saving business in difficulties, rather than protecting the working classes from the risks to their subsistence. ${ }^{24}$

It would be possible to argue, however, that all these measures are temporary and that, after the pandemic, neoliberal policies will resume its dominance. This hypothesis seems implausible, precisely in light of the hegemonic crisis discussed before. Although capitalist domination depends on a huge coercive apparatus, it cannot last without a minimum of consent. It is symptomatic that an influent mouthpiece of the ruling classes like the Financial Times has launched, in 2019, a platform titled Capitalism, time for a reset. The transformations entailed by the fight against the pandemic may be the last impulse that was missing to redefine the terms of this domination, not least because the pandemic itself tends to deepen the hegemonic crisis, aggravating one of its main triggers: inequality (Nassif-Pires et al., 2020; see also, Harvey, 2020). If the bets that neoliberalism had come to an end were premature in 2008, more than a decade later, amid an open hegemonic crisis and a catastrophe of the dimension of the pandemic, it seems safer to anticipate its end. ${ }^{25}$

If the fight against the pandemic leads to the abandonment of neoliberal policies, do we have something to celebrate? After diagnosing the hegemonic crisis, Fraser admits: "I can't pretend to be unhappy about that" (Fraser and Jaeggi, 2018: 298). There is no doubt that the overcoming of neoliberalism represents a historical opening for a deeper struggle about the future of our societies. But the possibility that the change will have more regressive than emancipatory elements should not be dismissed. ${ }^{26}$ The fact that state surveillance, which was already spreading for some time, acquired centrality as a means of defeating the pandemic (one of the requirements of the testing and tracking strategy) suggests caution. Nothing guarantees that the banalization of the tracking of mobile phones and the dissemination of facial recognition technology will be reverted once the virus is under control. As Marco D'Eramo (2020: 24) argued, "[t]hat coronavirus is being exploited to strengthen mass-surveillance infrastructure is no secret". Additionally, the fact that governments less restricted by democratic institutions (like China) have shown to be more effective in

\footnotetext{
${ }^{22}$ As Grigera notes, the IMF is tracking the economic policy measures adopted in light of the pandemic: https:/www.imf.org/en/Topics/imf-and-covid19/Policy-Responses-to-COVID-19.

${ }^{23}$ For more detailed analyses, see Tooze (2020), Saad-Filho (2020), and Brenner (2020).

${ }^{24}$ That does not mean that there is necessarily a dilemma, in this specific context, between protecting the workers or the firms. See, on this issue, Saez and Zucman (2020).

${ }^{25}$ It is not unlikely that the overcoming of neoliberalism will happen in a geographically uneven way, affecting differently each of the knots of the triangular articulation. However, I prefer to abstain from making specific suggestions in this regard.
}

${ }^{26}$ See, for an earlier convergent analysis, Bresser-Pereira (2015). 
fighting the pandemic may increase the appeal of authoritarianism. ${ }^{27,28}$ One should not, of course, overestimate how effectively democratic are the liberal democracies, with their mechanisms of participation increasingly limited and hollowed out. But the risk that the trend is towards authoritarian alternatives rather than towards the radicalization of democracy should be borne in mind, which would deepen the process that is being carried away by far-right governments. ${ }^{29} \mathrm{~A}$ redefinition of the terms of capitalist domination does not exclude the possibility of a new combination of consent and coercion that leans more towards the latter.

This authoritarian state-managed capitalism is not, however, the only horizon available. Another overcoming of neoliberalism is conceivable. It could entail, for instance, the universalization of the right to healthcare, bringing the austerity policies that damage the sector to an end. It could also attenuate the unbalance of capital/labor relations by resorting to universal basic income policies (as long as the amount of the transfer is sufficient to reduce workers' compulsion to sell their labor power, instead of being only a low social transfer to attenuate extreme poverty). ${ }^{30}$ Moreover, this alternative overcoming of neoliberalism would imply a substantial change of the tax systems, reverting the shifts that made them more regressive in the last few decades. This alternative could include as well a feminist redefinition of "the boundaries delimiting 'economy' from 'society', 'production' from 'reproduction', and 'work' from 'family" (Fraser, 2016: 103), overcoming the crisis of care and the lack of recognition for care work. ${ }^{31}$ Last, it could be the basis for replacing xenophobic discourses with international cooperation and solidarity.

Such elements do not seem to be, currently, utopian projects unconnected to social tendencies. The fight against the pandemic not only stimulates the consolidation of authoritarian surveillance apparatus but also encourages the formation of support networks and the adoption of policies that could create the bases for an emancipatory transformation of society. The flourishing of solidarity community

\footnotetext{
${ }^{27}$ Isabella Weber, Hao Qi, and Zhongjin Li (2020), in a welcome effort to confront the orientalism that characterizes part of the Western left, recently argued that the effectiveness of China's strategy against the virus was because it is not neoliberal, rather than because it is not democratic. Although there is no doubt that neoliberal policies have hampered significantly the efforts to face the health crisis, in several countries, it is hard to disentangle, in China's particular case, the economic planning from the political system. The struggle for an emancipatory overcoming of neoliberalism indeed requires arguing that the best way to face current and future crises is with more democracy and less neoliberalism. However, the usefulness of China's example for this ideological dispute seems to be limited.

${ }^{28}$ It also increases the chances of a hegemonic transition, from the United States to China, although the strengthening of the dollar and the unbalance of the military apparatuses of the two countries suggests caution in this regard.

29 This does not mean, of course, that the strategy of some of them, like Bolsonaro and Trump, of denying the seriousness of the pandemic will be electorally successful. In case it backfires, their authoritarian projects will likely be taken over by others.

${ }^{30}$ As proposed, for instance, by Andrew Glyn (2006: 178-83).

${ }^{31}$ See, on that, Dos Santos (2020).
} 
initiatives, the centrality acquired by care work, and the recent valorization of health workers allow a glimpse of the possibility of a radical reorganization of society, from the bottom up, taking advantage of the worldwide strengthening of feminist movements in the last few years and of local political initiatives that have been spreading since the global protest wave that broke out in 2010. Simultaneously, the current crisis tends to increase significantly government debt, making the defense of austerity unfeasible and pushing towards a renegotiation of the fiscal bases of the states. ${ }^{32}$ The nature of this renegotiation and of that reorganization will depend on the capacity of the working classes to organize politically to lead the reconstruction process that will follow the pandemic. The huge unemployment rates that will result from the crisis tend to weaken the vast majority. But the deepening of the hegemonic crisis means that there are also fragilities in the side of the ruling classes.

Neoliberalism, like Quincas Berro D’Água, may have more than one death. The dispute to define it is still open. As Arundhati Roy (2020) recently wrote: "We can choose to walk through [the pandemic], dragging the carcasses of our prejudice and hatred, our avarice, our data banks and dead ideas, our dead rivers and smoky skies behind us. Or we can walk through lightly, with little luggage, ready to imagine another world. And ready to fight for it."

\section{REFERENCES}

BARBA, Aldo, PIVETTI, Massimo (2009). "Rising household debt: its causes and macroeconomic implications, a long-period analysis”, Cambridge Journal of Economics, Vol. 33, pp. 113-37.

BLECKER, Robert (2016). “The US economy since the crisis: slow recovery and secular stagnation”, European Journal of Economics and Economic Policies: Intervention, Vol. 13 (2), pp. 203-214.

BRENNER, Robert (2020). “Escalating plunder”, New Left Review, n. 123, pp. 5-22.

BRESSER-PEREIRA, Luiz Carlos (2015). "After the demise of neoliberalism, a third (conservative) developmentalism?” EESP/FGV Discussion Paper, n. 394.

BRESSER-PEREIRA, Luiz Carlos (2017). "The two forms of capitalism: developmentalism and economic liberalism”, Brazilian Journal of Political Economy, Vol. 37 (4), pp. 680-703.

CARVALHO, Laura (2019). "Fundamentalismo de Mercado pode ser calcanhar de aquiles de Bolsonaro", Folha de São Paulo, Ilustríssima, December $1^{\text {st. }}$.

DAVIS, Mike (2017). “Election 2016”, New Left Review, n. 103, pp. 5-8.

D’ERAMO, Marco (2020). “The philosopher's epidemic”, New Left Review, n. 122, pp. 23-28.

DOS SANTOS, Paulo (2020). "Time for a rethink on the worth of work", Developing Economics, April 2nd (https://developingeconomics.org/2020/04/02/time-for-a-rethink-on-the-worth-of-work/).

DUMÉNIL, Gérard, LÉVY, Dominique (2004). "Neoliberal income trends: wealth, class and ownership in the USA", New Left Review, n. 30, pp. 105-133.

DUMÉNIL, Gérard, LÉVY, Dominique (2011). The Crisis of Neoliberalism, Cambridge, Mass.: Harvard University Press.

\footnotetext{
32 That would be in line with the historical trend, identified by Piketty, of tax systems becoming more progressive after large conflicts, as Cicero Araújo has noticed. According to Piketty (2014: 498-502), progressive taxation in the 20th century was "an ephemeral product of chaos".
} 
ERTEN, Bilge, OCAMPO, José Antonio (2012). "Super cycles of commodity prices since the mid-nineteenth century”, World Development, Vol. 44, pp. 14-30.

FERNANDES, Sabrina (2019). Sintomas Mórbidos: a encruzilhada da esquerda brasileira. São Paulo: Autonomia Literária.

FERNÁNDEZ, Brais (2020). “Spain's hospitals have suffered death by a thousand cuts”, Jacobin, March 30th (https://jacobinmag.com/2020/03/coronavirus-spain-hospitals-public-health-care-austerity).

FIGUEIREDO SANTOS, José Alcides (2015). “Classe social e deslocamentos de renda no Brasil”, Dados, Vol. 58 (1), pp. 79-110.

FOGEL, Robert (2001). “Simon S. Kuznets, 1901-1985”, Biographical Memoirs, Vol. 79, pp. 203-230.

FRASER, Nancy (2016). “Contradictions of capital and care”, New Left Review, n. 100, pp. 99-117.

FRASER, Nancy (2019). The Old is Dying and the New Cannot Be Born: from progressive neoliberalism to Trump and beyond. London: Verso.

FRASER, Nancy, JAEGGI, Rahel (2018). Capitalism: a conversation in critical theory. Edited by Brian Milstein. Cambridge: Polity.

GALLAGHER, Kevin (2016). The China Triangle: Latin America's China boom and the fate of the Washington consensus. Oxford: Oxford University Press.

GERBAUDO, Paolo (2017). The Mask and the Flag: populism, citizenism and global protest. Oxford: Oxford University Press.

GILENS, Martin, PAGE, Benjamin (2014). “Testing theories of American politics: elites, interest groups, and average citizens", Perspectives on Politics, Vol. 12 (3), pp. 564-581.

GLYN, Andrew (2006). Capitalism Unleashed: finance, globalization, and welfare. Oxford: Oxford University Press.

GOPINATH, Gita (2020). “The great lockdown: worst economic downturn since the Great Depression”, IMF Blog, April 14th (https://blogs.imf.org/2020/04/14/the-great-lockdown-worst-economic-downturn-since-the-great-depression/).

GRAMSCI, Antonio (1971). Selections from the Prison Notebooks. Edited and translated by Q. Hoare and G. N. Smith. New York: International Publishers.

GRIGERA, Juan (2020). "Salt in the wound: the crises of Covid-19", Spectre, May 27th (https://spectrejournal.com/salt-in-the-wound/).

HACKER, Jacob, PIERSON, Paul (2010). "Winner-take-all politics: public policy, political organization, and the precipitous rise of top incomes in the United States", Politics and Society, Vol. 38 (2), pp. 152-204.

HARVEY, David (2020). “Anti-capitalist politics in the time of Covid-19”, Jacobin, March 20th (https:// jacobinmag.com/2020/03/david-harvey-coronavirus-political-economy-disruptions).

HAZELDINE, Tom (2017). "Revolt of the rustbelt”, New Left Review, n. 105, pp. 51-79.

KIM, Yun K., LIMA, Gilberto Tadeu, SETTERFIELD, Mark (2019). "Political aspects of household finance: debt, wage bargaining, and macroeconomic (in)stability", Journal of Post Keynesian Economics, Vol. 42 (1), pp. 16-38.

LEVENSON, Zachary (2020). “An organic crisis is upon us: when Gramsci goes viral”, Spectre, April 20th (https://spectrejournal.com/an-organic-crisis-is-upon-us/).

LOPÉZ, Isidro, RODRÍGUEZ, Emmanuel (2011). “The Spanish model”, New Left Review, n. 69, pp. 5-29.

LOUREIRO, Pedro Mendes (2018). The Ebb and Flow of the Pink Tide: reformist development strategies in Brazil and Argentina. Ph.D. Dissertation, Department of Economics, SOAS, University of London.

MARX, Paris (2020). "Nationalize the airlines", Jacobin, March 25th (https://jacobinmag.com/2020/03/ nationalize-airline-industry-coronavirus-climate-emissions).

MEDEIROS, Carlos Aguiar de (2010). "O ciclo recente de crescimento chinês e seus desafios", Observatório da Economia Global (Unicamp), n. 3

MILANOVIC, Branko (2016). Global Inequality: a new approach for the age of globalization. Cambridge, Mass.: Harvard University Press.

MILANOVIC, Branko (2019). Capitalism, Alone: the future of the system that rules the world. Cambridge, Mass., Belknap Press. 
MOODY, Kim (2020). “How 'just-in-time’ capitalism spread Covid-19”, Spectre, April 8th (https://spectrejournal.com/how-just-in-time-capitalism-spread-covid-19/).

MORGAN, Mary, RUTHERFORD, Malcolm (1998). “American economics: the character of the transformation", History of Political Economy, Vol. 30 (Supplement), pp. 1-26.

NASSIF-PIRES, Luiza, XAVIER, Laura, MASTERSON, Thomas, NIKIFOROS, Michalis, RIOS-AVILA, Fernando (2020). "Pandemic of inequality", Public Policy Brief, n. 149, Levy Economics Institute.

PÉREZ-AHUMADA, Pablo (2018). "Social classes, economic sectors and changes in the Chilean social structure, 1992 and 2013”, Cepal Review, n. 126, pp. 155-175.

PIKETTY, Thomas (2014). Capital in the Twenty-First Century. Cambridge, Mass.: Harvard.

POLLOCK, Friedrich (1941). "State capitalism: its possibilities and limitations", Studies in Philosophy and Social Science, Vol. IX (2), pp. 200-25.

ROY, Arundhati (2020). "The pandemic is a portal”, Financial Times, April $3^{\text {rd }}$.

RUGITSKY, Fernando (2019). "Questão de estilo: a mudança estrutural para a igualdade e seus desafios”, in: CHILIATTO-LEITE, Marcos Vinicius (Ed.), Alternativas para o Desenvolvimento Brasileiro: novos horizontes para a mudança estrutural com igualdade. Santiago (Chile): CEPAL, pp. 75-95.

RUGITSKY, Fernando (2020). "Luta de classes inibida? Furtado e a especificidade da estrutural social brasileira", in: SAES, Alexandre, BARBOSA, Alexandre (eds.). Celso Furtado e os 60 anos de Formação Econômica do Brasil. São Paulo: BBM/Sesc, pp. 275-300.

SAAD-FILHO, Alfredo (2020). "From Covid-19 to end of neoliberalism", Critical Sociology, advanced access.

SAEZ, Emmanuel (2013). "Striking it richer: the evolution of top incomes in the United States", RealWorld Economics Review, n. 65, pp. 120-128.

SAEZ, Emmanuel, ZUCMAN, Gabriel (2020). “Jobs aren't being destroyed this fast elsewhere. Why is that?" The New York Times, March 30th (https://www.nytimes.com/2020/03/30/opinion/coronavirus-economy-saez-zucman.html).

SINGER, André (2012). Os Sentidos do Lulismo: reforma gradual e pacto conservador. São Paulo: Companhia das Letras.

SINGER, Paul (1981). Dominação e Desigualdade: estrutura de classes e repartição de renda no Brasil. Rio de Janeiro: Paz e Terra.

STORM, Servaas (2017). "The new normal: demand, secular stagnation, and the vanishing middle class", International Journal of Political Economy, Vol. 46, pp. 169-210.

STREECK, Wolfgang (2014). Buying time: the delayed crisis of democratic capitalism. London: Verso.

STREECK, Wolfgang (2016). How Will Capitalism End? Essays on a failing system, London: Verso.

TAYLOR, Lance, ÖMER, Özlem (2020). "Where do profits and jobs come from? Employment and distribution in the US economy", Review of Social Economy, Vol. 78, pp. 98-117.

TEMIN, Peter (2017). The Vanishing Middle Class: prejudice and power in a dual economy. Cambridge, Mass., MIT Press.

TOOZE, Adam (2018). Crashed: how a decade of financial crises changed the world. New York: Viking.

TOOZE, Adam (2020). "Shockwave”, London Review of Books, Vol. 42 (8).

VERNENGO, Matías (2020). "World War II, not the New Deal, is the model for Covid-19 macroeconomic policies”, Naked Keynesianism, March 21st (https://nakedkeynesianism.blogspot. com/2020/03/world-war-ii-not-new-deal-is-model-for.html?spref=tw).

WATKINS, Susan (2016). “Oppositions”, New Left Review, n. 98, pp. 5-30.

WEBER, Isabella, QI, Hao, LI, Zhongjin (2020). "China is not the enemy - neoliberalism is”, Jacobin, May $30^{\text {th }}$ (https://www.jacobinmag.com/2020/05/china-coronavirus-covid-response-wuhan-hubei).

WINTERS, Jeffrey, PAGE, Benjamin (2009). “Oligarchy in the United States?” Perspectives on Politics, Vol. 7 (4), pp. 731-751. 